\title{
(Natural) Science and Technique in Medicine: Teaching Competences along with Research Activities
}

\section{Johannes Lang, Holger Repp}

Faculty of Medicine, Dean's Office, Justus-Liebig-University Giessen, Germany.

\begin{abstract}
While factual knowledge is more and more present in digital format anywhere and anytime, (higher) education needs to extend its scope to supporting the development of personal skills and competences.

The teaching and learning project "(Natural) Science and Technique in Medicine - SciTecMed" is closely related to recent research in the intersectional field of natural science, technique and medicine. Local experts from the natural science and medical faculties engage in various teaching formats that are open for students of various majors. Together, students experience the idea of interdisciplinary collaboration, discuss from their individual perspectives and learn to learn from each other and to instruct each other. By the given context of the research activities, students earn insights into the scientific process and the usage of appropriate (digital) tools, enhance their corresponding skills and have the chance to take part into the scientific activities. We describe the concept of the project, potential obstacles, student's interests as well as the syndetic benefits for both sides education AND research.
\end{abstract}

Keywords: Interdisciplinarity, Scientific Competences, Learning Formats, Digitalisation, Medical Education, Research-Teaching 


\section{Introduction}

In times of ongoing technical developments, fake news, digital and steady availability of information higher education needs to shift from the delivery of pure knowledge to the development of competences and skills. It turns out, that in European countries like Germany, there are deficits in education of digital and technological skills and problemsolving competences (IMD, 2019, PIACC, 2013). Competences are currently being (re)defined, such as key competences like interactive usage of media, self-contained action as well as interaction in a heterogeneous environment (Rychen, 2003). As one important sector, the medical system is in need for much more digital offers and support systems (McKinsey, 2014), while the medical education itself is still in a transition process with no comprehensive and consistent approaches for digital education (Haag, 2018). The need of teaching scientific competences in medical education has been stated by the German Science Council (Wissenschaftsrat, 2014) and is politically manifested in the „Masterplan Medical Studies 2020" by the federal ministry of education and research (BMBF, 2017) and recently registered in the draft of a new medical approbation regulation along with interprofessional and communication competences (BMG, 2019). The OECD Education Ministers comprehensively phrase: "Sustainable development and social cohesion depend critically on the competencies of all of our population - with competencies understood to cover knowledge, skills, attitudes and values." (OECD, 2005).

\section{The Teaching Project SciTecMed}

The teaching and learning project "(Natural)Science and Technique in Medicine SciTecMed" (in German: "(Natur)Wissenschaft und Technik in der Medizin - NWTmed") is based on activities in the field of (natural) sciences and technical developments in medicine-related research. It has been launched to familiarise students with interdisciplinary and scientific working. Therefore, experts from across the disciplines engage in different teaching formats to reveal their research activities and underlying theories. The teaching offers are open for students from all fields of studies to share a common learning experience, stimulating the interdisciplinary exchange and fostering the mutual understanding and appreciation.

The project has been founded in 2018 at the Justus-Liebig-University in Giessen. There, one comes across quite advantageous conditions, since the Justus-Liebig-University, as a multi-discipline university, comprises a whole span of faculties and subjects. In our project SciTecMed we focus on the related faculties of "Mathematics and Computer Science, Physics, Geography" with approx. 3100 students and "Biology and Chemistry with approx. 2000 students, as well as the faculty of Medicine with approx. 3100 students. A close 
spatial and organizational connection to the neighboring TH Mittelhessen University of Applied Sciences favorably provides a good link to the engineering sciences.

So far, the academic program provides elective modules and extra-curricular offerings and can account for compulsory optional subject achievements in the individual course of studies. The teaching courses feature different formats ranging from lectures, seminars, lab practices, hands-on workshops to excursions, which addresses as many as possible of daily scientific routines (Tremp, 2012) and thereby serve various of research-teaching designs, such as Research-tutored, Research-based, Research-led and Research-oriented (Huber, 2014, Healey, 2005). The broad range of teaching formats and the degree of individual motivations and engagement aims for a level of highly development competences (Wildt, 2011). The communicative approach in real life is complementary to digital available knowledge and teaching courses and contributes to a sustainable learning (Draeger, 2015). In general, the project tends to a trustable relation between the experts and students as well to positive motivation as surety for effective learning (Al-Sugri, 2018). It is considered, that potential hurdles of getting into touch should be kept as low as possible in order to make students benefit from special teaching and supporting offers (Wild, 2019).

\section{Tentative Observations}

The SciTecMed project is continously being developed in many respects and offers academic courses since the past four terms (Lang \& Repp, 2018). Participating students stem from majors in e.g. biology, chemistry, law, economics, history, space technology, material science, mathematics, medicine, medical computing, physics and corresponding subjects. The number of engaged protagonists within the SciTecMed network $(>30$ protagonists) is constantly rising, which guarantees for a broad range of topics and expertise. Along with that, the number of courses is increasing, comprising offers like SciTecMed - overview into the field of (natural) science and technique in medicine and scientific working, artificial intelligence methods for medicine, natural science and life science, mass spectrometry in medicine and life science, inactivation of microbes by plasma sterilization, methods of nuclear physics measurements in medicine and life science, viso-haptic teaching of rheumatic and osteological diseases by virtual reality, emergency medical aid and technical rescue by firefighters, Neurotronics - how electronics may learn from biology, as well as practical handling on clinical trial data (SciTecMed, 2020). One result of the intense discussions with students is that there is an urgent need for courses that do not only use digital methods for the sake of knowledge delivery, but do handle modern methods as tool for their future career. Consequently, SciTecMed makes use of virtual reality for teaching and to discuss applications such as medical elucidation on patients (aerzteblatt, 2019). Besides its application e.g. in life science and medicine, the methods of 
artificial intelligence and much more its capacities, potentials and boundaries, as well as juristic and ethical aspects are being reconsidered (Lang \& Repp 2019).

In addition to that, a common master module with the partner university in Kazan (Kazan Federal University, Tartastan) is going to be launched, extending the SciTecMed portfolio. This master module is based on common virtual seminars (video conferencing e.g.) hosted by each university including tandem practical (lab) projects with the aim to facilitate international and cultural exchange of the "young" scientists in teaching, learning and research by meeting virtually and in real.

In order to coordinate and guarantee for the acceptance as study achievements, the project is in close touch with the responsible offices of student affairs. It needs quite an amount of coordination efforts to create time wise arrangements that meet students' constraints of the different subjects and faculties. Content wise, there is always a heterogeneous level of prior knowledge and skills of the participants, especially considering their completely diverse curricula. This fact turns out as a good starting point and chance to engage skilled students themselves as teachers for their fellow students, which elevates their own level of comprehension. The rate of participation of the SciTecMed courses fluctuates within the terms and offers. It is observable that this strongly depends on the extent of attention created for the project and the single topics. This may be due to the fact, that SciTecMed offers are currently elective modules as well as due to a broad variety of more intuitive offers within the own main subject. Nevertheless, participants appreciate the offers because of the specific contents, the training of competences and the authentic contact to the experts in the field as well as the face-to insights into scientific carriers. They finally recommend these courses for their fellow students and do not want to miss it by themselves.

A random sample survey was done across the courses to get an idea of the wishes and expectations of students that are willing to participate into the SciTecMed program. The according sample size amounts to $\mathrm{n}=39$. It is notably, that only 4 out of 39 confidentially state, that they have any prior research experience. The average number of participants' years of the university enrolment is 3,5. Figure 1 illustrates some of the considered aspects, where the students' interests are weighted with a Likert scale (ranging from 1 with shallow to 5 with highest interest).

It is notably, that students are eager to learn about scientific working and scientific organization, what has explicitly stated in many individual students' declarations. This seems to be of special interest for the passing of their theses. The interest in the context of SciTecMed is obvious, since they are taking part into SciTecMed program. Students are willing to spend time into specialized topics and deal with theory and approaches in depth, while practical courses and internships are little less appreciated. Overall, students are interested in interdisciplinary working and willing to take part into the research projects. 


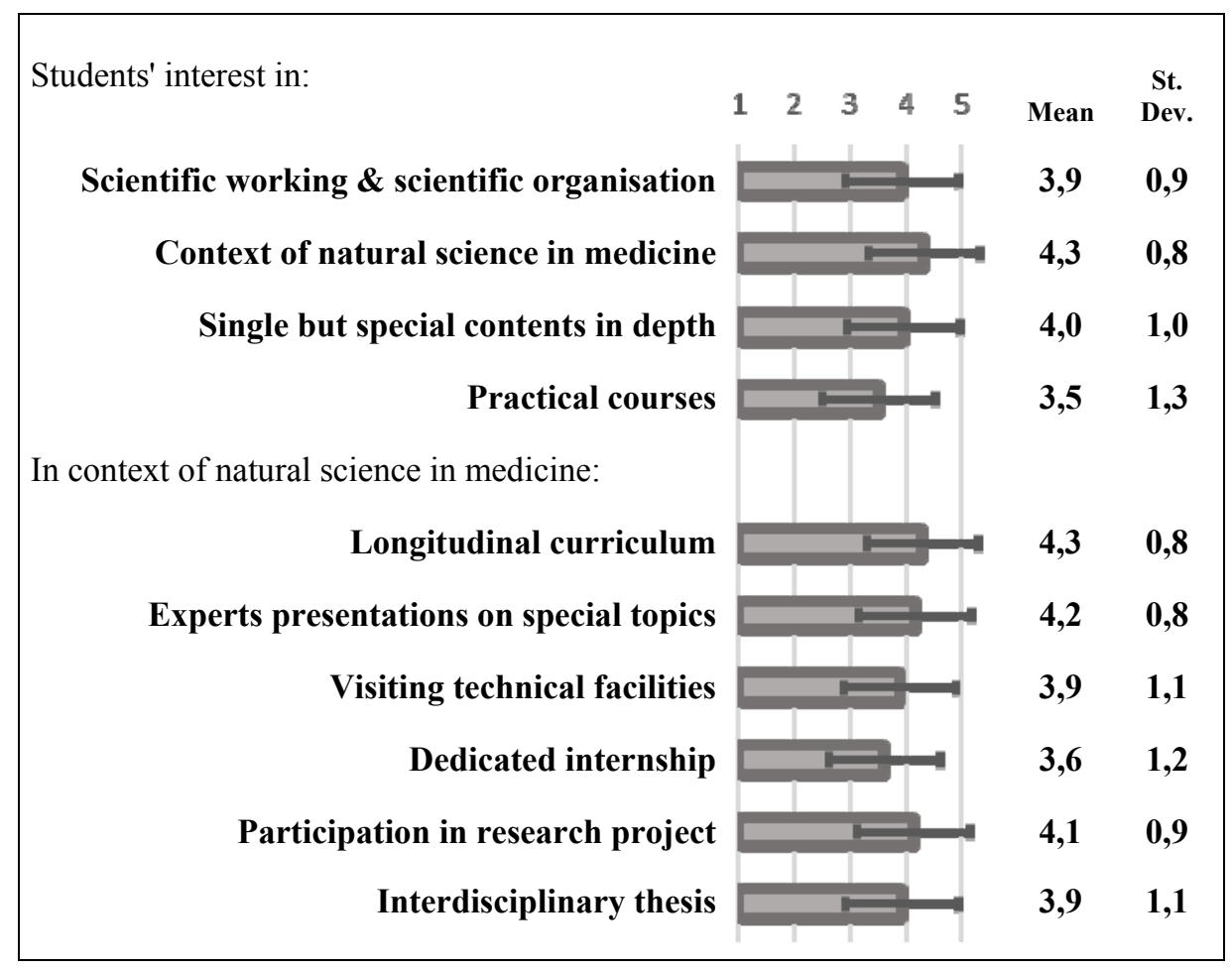

Figure 1. Participants' general interest and special interest on natural science in medicine (Likert scale).

The students' gain of skills and competences along with the teaching offerings in SciTecMed can be observed along the ongoing terms. Especially, their knowledge and sensitisation for required competences as well as their interest in and willingness to engage into research projects is increased. The exact amount of gain of the targeted competences and the tools to measure are part of further work in progress. In the supplemental material the practical benefit of interdisciplinary exchange and discussions compared to a "conservative" preaching of research is depicted. Besides the delvivery of pure knowledge, the students gain and train real competences as wel as lecturers and students both experience feedback of the whole teaching process. Further, there there are additional benefits for science, that can turn out eventually. According to Humboldt's fiction of universities (Wulf, 2016), there are regular beneficial side effects of the teaching activities, namely driving innovations in research itself. As we see in SciTecMEd, there are ideas for scientific theses drawn and pursued as well as clinical studies initiated such as the application of atmospheric plasma for orphan dermatological diseases - derived by the interdisciplinary interaction of lecturers and students among the SciTecMed courses (Lang, 2019, JLU, 2020). 


\section{Conclusion and Outlook}

A lively teaching and learning project based on research activities has been established with the aim to enhance scientific, interdisciplinary, international and digital competences. Structures for teaching and the acceptance of study achievements have been developed. While the gain and measurement of competences is still subject of recent investigation, the observations from the runtime of the project show a high acceptance and joy of the participating students. While there may be still an initial barrier for students to familiarise with these academic offers of this genre, the necessity of the corresponding competences and the benefits by joining such programs need to be clearly communicated to the students and more curricular modules should be established. Benefits regularly exist on both sides for students and lecturers, namely the enhancement of individual competences as well as creative ideas for research.

\section{Acknowledgements}

We would like to thank the State of Hesse, Giessen University and the German Academic Exchange Service (DAAD) for supporting this project. Further. We gratefully thank all the great and enthusiastic experts, lecturers and students engaging into our project and providing a sustainable and lively exchange.

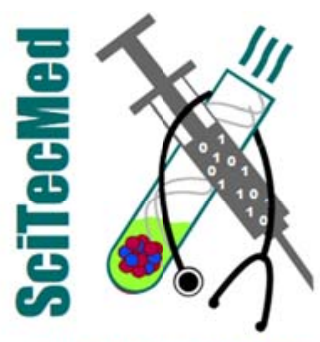

www.SciTecMed.org 


\section{References}

Aerzteblatt, (2009). Medizinstudierende in Gießen lernen mit Virtual-Reality-Brillen, www.aerzteblatt.de/nachrichten/104224/Medizinstudierende-in-Giessen-lernen-mitVirtual-Reality-Brillen

Al-Sugri M, Al-Kindi A, AlKindi S, Saleem N, (2018). Promoting Interdisciplinarity in Knowledge Generation and Problem Solving, in Advances in Knowledge Acquisition, Transfer, and Management (AKATM) Book Series, ISSN 2326-7607

BMBF, (2017). Masterplan Medizinstudium 2020, https:/www.bmbf.de/files/2017-0331_Masterplan\%20Beschlusstext.pdf

BMG, (2019). Arbeitsentwurf des Bundesministeriums für Gesundheit Approbationsordnung für Ärzte und Ärztinnen, (ÄApprO)

Draeger J, Mueller-Eiselt R, (2015). Die digitale Bildungsrevolution: Der radikale Wandel des Lernens und wie wir ihn gestalten können, Deutsche Verlags-Anstalt, ISBN 342104709X

Haag M, Igel C, Fischer MR, German Medical Education Society (GMA), Committee "Digitization - Technology-Assisted Learning and Teaching", Joint working group "Technology-enhanced Teaching and Learning in Medicine (TeLL)" of the German Association for Medical Informatics, Biometry and Epidemiology (gmds) and the German Informatics Society (GI), (2018). Digital Teaching and Digital Medicine: A national initiative is Needed, GMS J Med Educ. 2018;35(3):Doc43. DOI: $10.3205 / \mathrm{zma} 001189$

Healey M, (2005). Linking research and teaching: exploring disciplinary spaces and the role of inquiry-based learning, Political Science

Huber L, (2014) Forschungsbasiertes, Forschungsorientiertes, Forschendes Lernen: Alles dasselbe? In: Das Hochschulwesen. Nr. 62(1+2), S. 22-29

IMD WORLD COMPETITIVENESS / TALENT / DIGITAL RANKING 2019, MD WORLD COMPETITIVENESS CENTER, (2019).

Justus-Liebig-University Giessen (JLU), (2020). Mit Raumfahrttechnik gegen seltene Krankheiten, press release, https://www.uni-giessen.de/ueberuns/pressestelle/pm/pm17-20raumfahrttechnikgegenseltenekrankheiten

Lang J \& Repp H, (2018). Die (Natur)Wissenschaft und Technik im Medizinstudium, German Medical Science GMS Publishing House. Doc11.1., DOI: 10.3205/18gma050

Lang J \& Repp H, (2019). Künstliche Intelligenz im Medizinstudium: Nutzung der natürlichen Intelligenz durch interdisziplinäre Lehre, submitted to GMS J Med Educ

Lang J, Heinz S, Lange U, Linnyk O, Thoma M, Repp H, (2019). Plasmamedizin, künstliche Intelligenz, Kernreaktionen und wie wir interdisziplinär von- und miteinander lernen, German Medical Science GMS Publishing House; DocV26-06. DOI: $10.3205 / 19$ gma202

OECD Definition and Selection of Competencies, (2005). https://www.oecd.org/pisa/35070367.pdf

Rychen DS \& Salganik LH, (2003). Key Competencies for a Successful Life and a WellFunctioning Society, Hogrefe \& Huber, Göttingen 
SciTecMed, (Natural) Science and Technique in Medicine, (2020). (Natur)Wissenschaft und Technik in der Medizin - NWTmed, Homepage, www.uni-giessen.de/NWTmed

Tremp P \& Hildbrand T, (2012). Forschungsorientiertes Studium-universitäre Lehre: Das «Zürcher Framework» zur Verknüpfung von Lehre und Forschung, Bertelsmannverlag

Wild E, (2019). Diversity-Management Strategies of Universities and Technical Colleges in Germany Theoretical Reflections and Empirical Findings, Vortrag zu Ergebnissen des Projekts „HeLGA - Heterogenitätsorientierte Lehre - Gelingensbedingungen und Anforderungen“" auf der 32. CHER-conference, Kassel

Wildt J \& Wildt B, (2011). Neues Handbuch Hochschullehre, Teil H: Prüfungen und Leistungskontrollen. Weiterentwicklung des Prüfungssystems in der Konsequenz des Bologna-Prozesses (S. 1-46), in B. Berendt, H.-P. Voss \& J. Wildt (Hrsg.), Berlin: Raabe

Wildt J, (2011). Ein Blick zurück - Fachübergreifende und/oder fachbezogene Hochschuldidaktik: (K)eine Alternative?, Jahnke I [Hrsg.]; Wildt J [Hrsg.]: Fachbezogene und fachübergreifende Hochschuldidaktik, Bielefeld : Bertelsmann, S. 19-34 (Blickpunkt Hochschuldidaktik; 121)

Wissenschaftsrat, (2014). Empfehlungen zur Weiterentwicklung des Medizinstudiums in Deutschland auf Grundlage einer Bestandsaufnahme der humanmedizinischen Modellstudiengänge, https://www.wissenschaftsrat.de/download/archiv/4017-14.pdf

Wulf A, (2016). Alexander von Humboldt und die Erfindung der Natur, aus dem Amerikanischen von Hainer Kober, C. Bertelsmann Verlag, München 